\title{
UGT8 Gene
}

National Cancer Institute

\section{Source}

National Cancer Institute. UGT8 Gene. NCI Thesaurus. Code C113546.

This gene is involved in galactocerebroside synthesis. 